\title{
Polysaccharides Cell Wall Architecture of Mucorales
}

\author{
Karine Lecointe ${ }^{1,2}$, Marjorie Cornu ${ }^{1,2}$, Jordan Leroy ${ }^{1,2}$, Pauline Coulon ${ }^{1,2}$ \\ and Boualem Sendid ${ }^{1,2 *}$
}

${ }^{1}$ Lille Inflammation Research International Center, UMR 995 Inserm, Fungal Associated Invasive and Inflammatory Diseases, CHU Lille, Lille University, Lille, France, '2Laboratory of Parasitology and Mycology, Institute of Microbiology, CHU Lille, Lille, France

Invasive fungal infections are some of the most life-threatening infectious diseases in the hospital setting. In industrialized countries, the most common fungal species isolated from immunocompromised patients are Candida and Aspergillus spp. However, the number of infections due to Mucorales spp. is constantly increasing and little is known about the virulence factors of these fungi. The fungal cell wall is an important structure protecting fungi from the environment. A better knowledge of its composition should improve our understanding of host-pathogen interactions. Cell wall molecules are involved in tissue adherence, immune escape strategies, and stimulation of host defenses including phagocytosis and mediators of humoral immunity. The fungal cell wall is also a target of choice for the development of diagnostic or therapeutic tools. The present review discusses

Edited by:

Hector Mora Montes, Universidad de Guanajuato, Mexico

Reviewed by:

Everardo López-Romero, Universidad de Guanajuato, Mexico Rosana Puccia,

Federal University of São Paulo, Brazil

*Correspondence: Boualem Sendid boualem.sendid@univ-lille.fr

Specialty section: This article was submitted to Fungi and Their Interactions, a section of the journal

Frontiers in Microbiology

Received: 31 October 2018 Accepted: 22 February 2019

Published: 19 March 2019

Citation: Lecointe K, Cornu M, Leroy J, Coulon P and Sendid B (2019)

Polysaccharides Cell Wall

Architecture of Mucorales.

Front. Microbiol. 10:469.

doi: 10.3389/fmicb.2019.00469 our current knowledge on the cell wall structure of Mucorales in terms of the polysaccharides and glyco-enzymes involved in its biosynthesis and degradation, with an emphasis on the missing gaps in our knowledge.

Keywords: Mucorales, polysaccharides, cell wall, glucuronic acid, glyco-enzymes

\section{INTRODUCTION}

Fungal adherence is a prerequisite for colonization and invasion of the host leading to infection. Fungi have also developed strategies to escape the host defenses. The cell wall, a dynamic structure essential for cell viability and morphogenesis, is one of the barriers that protects fungi from environmental stress (Latgé and Calderone, 2002). It contains enzymes that could be secreted to facilitate degradation of host tissues in order to release nutrients essential for fungal metabolism, fungal growth, and tissue invasion. The cell wall also contains environmental sensors allowing fungi to resist stress, osmotic pressure, or toxic molecules (Latgé, 2010). Almost 90\% of the fungal cell wall is composed of polysaccharides not found in humans. These structures remain an ideal yet somewhat unrealized target for the development of new antifungal drugs. The cell wall structure of medically important opportunistic fungal pathogens has been well described (i.e., for Aspergillus fumigatus, Candida albicans, Pneumocystis spp., Cryptococcus neoformans, Histoplasma capsulatum, and Blastomyces dermatitidis). Fungal cell walls are organized in a similar way. Indeed, cell wall is composed of two layers: an inner layer which is the backbone part and an outer layer which is a kind of carbohydrate matrix. The backbone is composed of $\beta-1,3$ - and/or 1,6-glucan and chitin bound to protein or other polysaccharides. The outer layer is more variable among the species. In yeasts such as Candida species, highly mannosylated glycoproteins are found on it. Concerning Aspergillus fumigatus, $\alpha$-1,3-glucan, galactomannan, and 
galactosaminogalactan are found, but at conidia stage, there is a supplementary outer layer composed of hydrophobin and melanin. In C. neoformans, a gelatinous capsule of glucuronoxylomannan and galactoxylomannan masks polysaccharides cell wall (Gow et al., 2017). Glucan, chitin, and polymers of mannose residues are the most common polysaccharides making up the cell surface envelopes of fungal species.

However, little is known about the fine structure of the cell wall of Mucorales spp., a prevalent cause of fungal infection leading to significant morbidity and mortality (Walsh et al., 2004), mainly in immunocompromised and diabetic patients. The incidence of mucormycosis was underestimated in the past due to the low performance of diagnostic techniques based on conventional microbiological methods. With the recent improvement of molecular detection of fungal DNA (real-time PCR), the diagnostic is easier, non-invasive, and reliable. Mucormycosis represents the third invasive fungal infection in terms of overall mortality in France (Bitar et al., 2014). A retrospective study conducted from 1997 to 2006 provided a trend over a 10 -year period at national level in France. This study showed an increasing incidence from 0.7/million in 1997 to 1.2 /million in 2006 (Bitar et al., 2009). The annual incidence reported in the USA and Spain was 1.7 and 0.43/million, respectively (Petrikkos et al., 2012). The prevalence has been estimated at 0.01 to 0.2 per 100,000 inhabitants in Europe and in the USA, respectively, while this rate is 70 times higher in India (14 per 100,000 inhabitants) (Skiada et al., 2018). The most common Mucorales genera, such as Rhizopus, Mucor, and Lichtheimia, are involved in $70-80 \%$ of cases of mucormycosis, whereas the genera Cunninghamella, Saksenaea, Rhizomucor, Apophysomyces, Syncephalastrum, Cokeromyces, and Actinomucor are reported in only $1-5 \%$ of cases (Gomes et al., 2011). The main risk factors identified are hematologic malignancies (44\%), trauma (15\%), allografts (9\%), diabetes (9\%), cancers (5\%), and solid organ transplantation (4\%) (Skiada et al., 2011). The different clinical forms of mucormycosis are correlated with different risk factors. Sinus mucormycosis is predominant in patients with uncontrolled diabetes, while the invasive pulmonary form is more common in neutropenic patients and solid organ transplant recipients. Cerebral and disseminated forms are rare but are associated with high mortality rates (Roden et al., 2005). Cutaneous forms are mainly found in immunocompetent patients after trauma and contamination by environmental Mucorales spores. This review provides insights on the structural composition of the Mucorales cell wall and potential enzymes involved in cell wall biosynthesis.

\section{MUCORALES CELL WALL POLYSACCHARIDES}

Studies dealing with the structural composition of the Mucorales cell wall are scarce and have mainly focused on Mucor mucedo and ucor circinelloides (formerly Mucor rouxii).

\section{Chitosan and Chitin}

As for insects and crustaceans, fungi are characterized by the presence of chitin/chitosan, which participate in the rigidity of the glycan edifice of the cell wall. Chitin is a polymer of $\beta$ - $(1 \rightarrow 4)$-linked GlcNAc, while chitosan is composed of a polymer of $\beta$-(1 $\rightarrow 4)$-linked GlcNAc and more than $50 \% \mathrm{GlcNH}_{2}$ (Table 1). One of the methods used to study chitin/chitosan in M. mucedo was the use of nitrous acid, which discriminates chitin and chitosan. Nitrous acid only has an effect on deamination and depolymerization if the polymer carries free $-\mathrm{NH}_{2}$ groups. Thereby, chitosan is degraded into 2,5-anhydromannose. Following treatment with nitrous acid, the molar ratios of anhydromannose (AnMan), GlcNAc-AnMan, GlcNAc ${ }_{2}$-AnMan, GlcNAc ${ }_{3}^{-}$ AnMan, and GlcNAc were quantified as: 67:11:3:1:13 (Datema et al., 1977a,b). The proportion of chitin/chitosan may vary between spore and hyphal forms and also between species. In Mucorales, these proportions were estimated at $12 \%$ and approximately $40 \%$ for spores and hyphae, respectively (Campos-Takaki et al., 2014).

\section{Glucuronic Acid}

Polyuronides are polymers of glucuronic acid (GlcUA). The proportion of this polysaccharide is dependent on the stage of development of the fungus. In $M$. circinelloides, the proportion of polyuronides varies from $25 \%$ in sporangiophore walls to $12 \%$ in hyphae or yeast-like cell walls and less than $2 \%$ in spores (Bartnicki-Garcia and Reyes, 1968). In $M$. mucedo, treatment of hyphae with nitrous acid releases glycuronan that is soluble in water and linked in a non-covalent way to a polymer of glucosamine (Datema et al., 1977a,b). The proportion of glucuronic acid in these hyphal forms reaches approximately $12 \%(\mathrm{w} / \mathrm{w})$. Glycuronan is composed of fucose, mannose, galactose, and glucuronic acid with a molar ratio of: 5:1:1:6. Acid hydrolysis of glycuronan leads to polymers of glucuronic acid with properties of mucoric acid previously identified by Bartnicki-Garcia and Reyes (1968). During acid hydrolysis of polyuronides, two fractions are obtained, mucoran and mucoric acid. Mucoran is an easily hydrolyzable heteropolysaccharide made of $\mathrm{D}$-glucuronic acid, L-fucose, and D-mannose in a molar ratio of 5:2:3 and a small proportion of $\mathrm{D}$-galactose and glucose (BartnickiGarcia and Lindberg, 1971). Mucoric acid is a polysaccharide resistant to acid hydrolysis composed mainly of D-glucuronic acid (Bartnicki-Garcia and Reyes, 1968).

Mucoran can be extracted from sporangiophore cell walls after hydrolysis by $\mathrm{HCl}$. It can also be extracted from yeastlike cell walls by alkaline treatment with $\mathrm{KOH}$ and precipitation as a copper complex (Bartnicki-Garcia and Lindberg, 1971). This alkaline treatment was successfully used to partially characterize mucoran and to define its structure. Further characterization of mucoran was performed using the Hakomori method (methylation of mucoran), followed by reduction, hydrolysis, and conversion to partially methylated alditol acetates that were analyzed by gas 
TABLE 1 | Partial structure of cell wall polysaccharides found in Mucorales.

Chitin/Chitosan

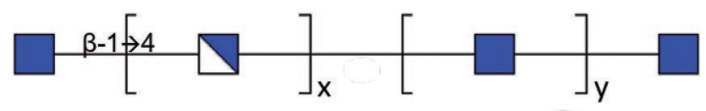

If GlcNAc (y) $>50 \% \longrightarrow$ chitin

If $\mathrm{GlcNH}_{2}(\mathrm{x})>50 \% \longrightarrow$ chitosan

Mucoran

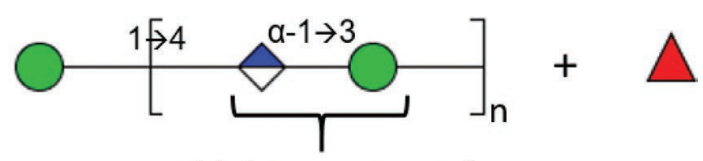

Aldobiouronic acid

Mucoric acid

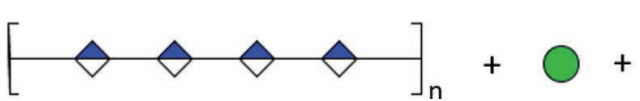

Glucan

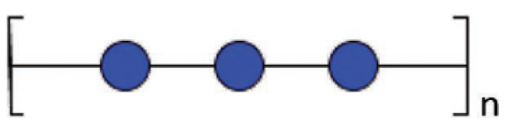

Fucose

$\mathrm{N}$-Acetylglucosamine

Mannose

$\square \quad$ Glucosamine

Glucose

Glucuronic acid

chromatography-mass spectrometry. This analysis showed that glucuronic acid is substituted at C-4, confirmed by the presence of 2,3-di-O-methyl-D-glucose (derived from 2,3-di-O-methyl-D-glucuronic acid), and mannose is substituted at C-3, confirmed by the presence of 2,4,6-tri-Omethyl-D-mannose. Both monosaccharides were found in the aldobiouronic acid material, which is recovered after partial acid hydrolysis of mucoran. Aldobiouronic acid is a disaccharide composed of $\alpha$-D-glucopyranosyluronic and acid-(1 $\rightarrow 3)$-D-mannose. Mucoran may correspond to long chains of D-Man- $\left(1 \rightarrow[4)-\alpha-D-G l c U A-(1 \rightarrow 3)\right.$-D-Man- $(1-]_{n}$ (Bartnicki-Garcia and Lindberg, 1971). The molecular mass of mucoran was estimated by gel filtration and varied depending on the form of the cells that the polysaccharide was derived from. Its molecular mass varied from $19.2 \mathrm{kDa}$ in the mycelial form to $34.8 \mathrm{kDa}$ in yeast-like cells (Dow et al., 1983a,b). In contrast to mucoran, mucoric acid has a similar molecular mass $(32-33 \mathrm{kDa})$ in sporangiophores, mycelium, or yeast-like cell walls. The monosaccharide composition revealed that mucoric acid is composed of $>90 \%$ glucuronic acid, 5\% glucose, 2\% mannose, and traces of galactose and fucose (Dow et al., 1983a,b) (Table 1).

\section{Glucan and Melanin}

In contrast to hyphae or yeast-like cells, glucan was found to be the major component of the spore cell wall in
M. circinelloides in association with melanin, glucosamine, mannans, and proteins. The corresponding abundance has been quantified in spore cell walls as follows: $9.5 \%$ glucosamine, $2.1 \%$ GlcNAc, $42.6 \%$ glucose, $4.8 \%$ mannose, $16.1 \%$ proteins, $10 \%$ lipids, $2.6 \%$ phosphate, and $10.3 \%$ melanin (Bartnicki-Garcia and Reyes, 1964). This study suggests that glucan synthesis may decrease during spore germination leading to modification of the cell wall glycoshield. The transition from spores to hyphal cells is probably due to de novo synthesis of a cell wall underneath the spore wall during germination. Despite progress in our understanding of the Candida and Aspergillus cell wall structure, little is known about Mucorales cell wall remodeling in different growth conditions and during tissue invasion. An elegant study demonstrated the presence of glucan in $M$. ramannianus spores (Jones et al., 1968) using $\beta$-glucanase obtained from culture fluid of Streptomyces spp. By microscopy, the authors showed that the spore cell wall is composed of two layers: an outer electron-dense layer and an inner thicker layer composed of microfibrils containing glucans, cleavable by lytic enzymes found in culture fluid of Streptomyces spp. A more recent study showed the presence of $\beta$-glucan on Rhizopus oryzae by confocal microscopy and its role in the production of IL-23 and the triggering of $\mathrm{T}_{\mathrm{H}^{-}}-17$ responses in dendritic cells via dectin-1 (Chamilos et al., 2010). 


\section{MUCORALES EXTRACELLULAR POLYSACCHARIDES}

Mucorales also secrete extracellular polysaccharides (EPS), which have been studied in several species of Rhizopus and Mucor. The structures and molecular mass of these EPS depend on the species from which they were isolated. These polysaccharides are essentially composed of $\beta 1,4$-linked glucuronic acid. These EPS are composed of mannose varying from 8 to $30 \%$; galactose from 4 to $13 \%$; fucose from 9 to $25 \%$; glucose from 0 to $30 \%$; and glucuronic acid from 32 to $55 \%$ (de Ruiter et al., $1991,1992)$. One study showed that mannose residues could be 2-O-methylated (de Ruiter et al., 1994). 2-O-methyl-Dmannose represents 1-2\% of the two mannan fractions extracted from EPS of $M$. racemosus. Mannose residues are linked through $\alpha 1,2$ linkages, while 2-O-methyl-D-mannose residues are found at the non-reducing end.

\section{ENZYMES INVOLVED IN CELL WALL BIOSYNTHESIS}

\section{Endohydrolases}

Enzymes have been implicated in biosynthesis of the fungal cell wall, notably during hyphal extension. There is a balance between synthesis and lysis of cell wall polysaccharides at the hyphal apex. Culture filtrates of $M$. circinelloides have been analyzed by gel filtration and showed the presence of uronides with several degrees of polymerization as tri-, penta-, or hexasaccharides. Analysis of these oligosaccharides showed glucuronic acid as the major part with traces of mannose, galactose, and fucose. Experiments with cycloheximide on $M$. circinelloides inhibited hyphal extension, but uronide production was unaffected suggesting a role of endohydrolases in cell wall remodeling (Dow and Villa, 1980).

\section{Glucuronosyl Transferase}

Experiments conducted by Dow et al. (1983a,b) showed glucuronosyl transferase activity in membrane fractions from yeast-like and mycelial forms of $M$. circinelloides. This enzyme is implicated in polyuronide biosynthesis and is involved in the transfer of D-GlcUA from uridine- $5^{\prime}$-diphosphoglucuronic acid (UDP-GlcUA) to endogenous acceptors. The acceptors are glycoproteins and polyuronides, such as mucoric acid and mucoran, found in the cell wall. The enzymes are characterized by a $\mathrm{pH}$ optimum between 7.0 and 8.0 for mycelial extracts, but enzymes found in yeast extracts have a lower optimum $\mathrm{pH}$ varying from 6.5 to $7.0 . \mathrm{Mn}^{2+}$ ions are required for maximal activity of enzymes from both sources (Flores-Carreón et al., 1985).

\section{Fucosyl Transferase}

As fucose is found in the zygomycete cell wall, there are probably some enzymes involved in the transfer of L-fucose from GDP-fucose to polysaccharides. Fucosyl transferase activity has been partially characterized and detected in membrane fractions from $M$. circinelloides. This fucosyl transferase has optimal activity at $\mathrm{pH} 6.5$ and at a temperature between 22 and $28^{\circ} \mathrm{C}$. This enzyme also requires the presence of metal divalent cations such as $\mathrm{Mn}^{2+}, \mathrm{Mg}^{2+}, \mathrm{Co}^{2+}, \mathrm{Zn}^{2+}, \mathrm{Fe}^{2+}$, and $\mathrm{Ca}^{2+}$. It has been shown that mucoric acid was not only an acceptor of fucosyl residues but also an activator of the enzyme (Camacho-Aguero et al., 1990).

\section{Chitin Synthase and Deacetylase}

Chitin synthesis is catalyzed by the transfer of GlcNAc from UDP-GlcNAc to chitin by chitin synthase. Chitosan is produced by deacetylation of chitin by chitin deacetylase. A chitin deacetylase has been partially purified and characterized from $M$. circinelloides. It was found in the supernatant of disrupted mycelia of $M$. circinelloides centrifuged at $20000 \mathrm{~g}$ and in culture media. This enzyme seems to be cytoplasmic and is released into culture media (Araki and Ito, 1975). Chitosan synthesis is not only due to chitin deacetylase activity; this enzyme works in tandem with a chitin synthase (Davis and Bartnicki-Garcia, 1984a,b). In this study, the authors showed that chitin is a precursor of chitosan. They also showed that incubation of both enzymes with UDP-GlcNAc led to the conversion of $10-15 \%$ of the substrate to chitosan within a 30 -min period. The reduction in the amount of chitin was correlated with an increase in chitosan. This chitin deacetylase has an apparent molecular mass varying from 75 to $80 \mathrm{kDa}$. It is a highly mannosylated glycoprotein and the minimum substrate required for its activity is a chitotetraose. The enzyme is inhibited by carboxylic acids, particularly acetic acid (Kafetzopoulos et al., 1993).

Concerning chitin synthase, a membrane-bound enzyme was purified and characterized from Absidia glauca (Machida and Saito, 1993). This enzyme was purified in zymogen form and was converted to its active form by trypsin. The active form had a molecular mass of $28.5 \mathrm{kDa}$, and its activity was stimulated by GlcNAc and inhibited by UDP analogues like polyoxin D. Lending et al. (1991) also isolated 16S chitin synthase particles from cell walls of $M$. circinelloides. Several polypeptides were purified, but only a polypeptide at $21 \mathrm{kDa}$ displayed enzyme activity.

\section{Chitinases}

A chitinase has been purified from the cytosol of $M$. circinelloides. This chitinase has better activity on nascent free chitin synthesized by chitin synthase than on more polymerized chitin. This digestion leads to a release of diacetylchitobiose as the main product (Lopez-Romero et al., 1978, 1982). Organized long microfibrils of chitin seem to be less accessible to chitinases. The chitinase activity found in M. circinelloides corresponded to two enzymes. This enzymatic activity was also dependent on the culture age (Pedraza-Reyes and LopezRomero, 1989). There was a peak in activity after $4 \mathrm{~h}$ of culture corresponding to germination (i.e., the cell wall 
remodeling phase). Another peak of activity was detected after $10 \mathrm{~h}$ during the mid-exponential growth phase. Chitinase I has a molecular mass of $30 \mathrm{kDa}$, whereas chitinase II has a molecular mass of $24 \mathrm{kDa}$.

\section{Chitosanases}

Two endochitosanases, A and B, were purified from autolyzed cultures of $M$. circinelloides. Their molecular masses were $76 \mathrm{kDa}$ and $58 \mathrm{kDa}$, respectively. These enzymes released the dimer and trimer of glucosamine, respectively, derived from chitosan (Alfonso et al., 1992).

\section{1,3- $\beta$-Glucan Synthase}

In fungal pathogens, such as A. fumigatus and C. albicans, glucan synthesis is well documented and involves a multisubunit complex composed of an integral membrane protein and a regulatory subunit, encoded by members of the FKS and RHO1 gene families. The presence of the FKS gene was also reported in Rhizopus oryzae (Ibrahim et al., 2005). The gene was cloned and sequenced. The deduced amino acid sequence revealed $64 \%$ conservation with other members of the Fksp family found in S. cerevisiae, C. albicans, C. neoformans, and A. fumigatus. Glucan synthase activity was measured by incubation of crude membranes from $R$. oryzae with UDP-glucose. Radiolabeled products were found and were susceptible to digestion with exo-1,3- $\beta$-D-glucanase. This activity was inhibited by caspofungin.

More recently, the genome sequence of $R$. oryzae strain 99-880 has been published using Sanger sequencing technology (Ma et al., 2009). A large number of glyco-enzymes potentially implicated in cell wall synthesis and remodeling have been annotated following the CAZy annotation pipeline (Battaglia et al., 2011). Notably, $R$. oryzae genome contains 21 CAZymes related to chitin cell wall modification and recycling including 34 chitin deacetylases; 43 related to chitosan including 3 chitosanases; 27 related to $\beta 1,3$-glucan including 3 putative $1,3-\beta$-D-glucan synthases; 5 related to $\alpha$-1,3-glucan; and 7 related to $\beta$-1,6-glucan. However, these last groups of genes would have a role in the cell wall degradation of other fungi like Ascomycetes.

\section{SIALOGLYCOPROTEINS AND URONIC ACID-CONTAINING GLYCOPROTEINS}

Glycoproteins were found in the cell wall of Mucorales that could interact with host cells. Recently, an attempt was made to characterize the nature of these glycoproteins. For this purpose, lectin-binding assays were set up with spores and yeast cells from clinical isolates of the dimorphic fungus M. polymorphosphorus. The spores were incubated with lectins with an affinity for sialic acids, such as Limulus polyphemus (LPA), Sambucus nigra (SNA), and Maackia amurensis (MAA) lectins. SNA recognizes $\alpha-2,6$ linked sialic acids, MAA recognizes $\alpha-2,3$ linked sialic acids, and LPA recognizes sialic acids with any type of linkage. These authors demonstrated the presence of both $\alpha-2,6$ - and $\alpha$-2,3-linked sialic acid residues in the spore cell wall. By Western blot, they also showed that the sialic acid residues were found on cell wall glycoproteins. Sialic acids seem to protect fungi against phagocytosis by human neutrophils and monocytes (Almeida et al., 2013).

Glycoproteins containing uronic acid were also detected in the cytoplasm and cell wall from $M$. circinelloides. These proteins had a molecular mass of $16.5 \mathrm{kDa}$. The calculated ratio of protein/uronic acid was 0.33 , representing two-thirds of the glycan part of these proteins. It was suggested that these glycoproteins could be a potential acceptor for chain initiation during polyuronide biosynthesis (Mormeneo et al., 1995).

\section{CONCLUSION}

Compared to other fungal pathogens, the precise structure of Mucorales cell wall remains unknown. Some polysaccharides have been described such as mucoran, mucoric acid, chitin, and chitosan for $M$. circinelloides and $M$. mucedo. The proportion of these polysaccharides in other Mucorales spp. involved in human infections remains to be determined (i.e., Lichtheimia corymbifera, $R$. arrhizus, and $R$. microsporus). Contrary to generally accepted ideas, the presence of $\beta$-glucan in the cell wall of $M$. circinelloides and $R$. oryzae spores was reported in 1964 and 2005, respectively. However, only two studies have described the existence of $\beta-1,3$ glucan synthase similar to that found in other fungal species belonging to the Ascomycetes (Ibrahim et al., 2005; Angebault et al., 2016). Mannose is also found in the cell wall of Mucorales, either in polysaccharides or in glycans. Moreover, the ALG2 gene was reported in $R$. pusillus and was considered as a homologue of genes found in $S$. cerevisiae and encoding a glycosyltransferase playing a role in the mannosylation of Man2GlcNAc2-dolichol diphosphate (PP-Dol) and Man1GlcNAc2-PP-Dol leading to Man3 GlcNAc2-PP-Dol (Yamazaki et al., 1998). Protein O-mannosyltransferase, reported in the most common medically important pathogens (C. albicans and A. fumigatus), has never been reported in Mucorales spp. For Mucorales, there are still many gray areas concerning the enzymes involved in the biosynthesis and degradation of the cell wall, notably during the germination of spores (Figure 1). The role of Mucorales cell wall polysaccharides in triggering host immune response is not clear. Stimulation of immune response is dependent of the developmental stage of Mucorales (spores, germ tube or hyphae). Concerning the early steps of dissemination in blood vessels, it was reported that Rhizopus spores adhere to laminin and type IV collagen of the basement membranes (Bouchara et al., 1996). Moreover, germinating spores of Rhizopus interact with epithelial cells by a specific recognition through GRP78, a host receptor glucoseregulator protein on host membrane cells, and CotH3, a protein belonging to the spore coating protein family 


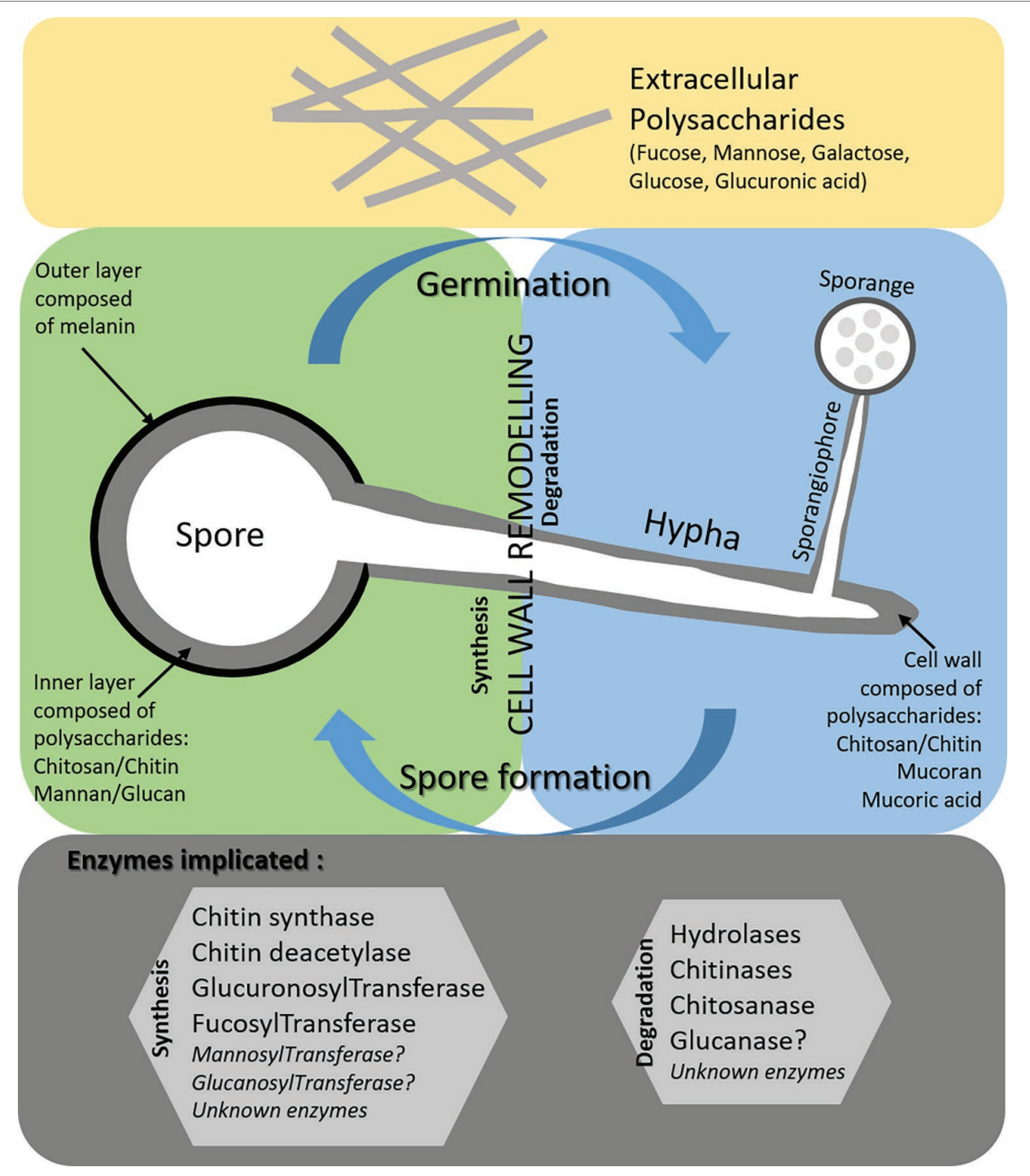

FIGURE 1 | Current knowledge on the cell wall of Mucorales spores (green part) and hyphae (blue part) and gaps (gray part).

(Gebremariam et al., 2014). Concerning phagocytic cells, macrophages can inhibit spore germination but cannot kill them. When spores are germinating, they are more susceptible to the damage by macrophages and neutrophils (Ghuman and Voelz, 2017) probably linked to the exposure of PAMPs of the cell wall. A better knowledge of the cell wall structure in term of polysaccharides will improve our understanding of the interaction between the host and Mucorales pathogens and will promote a better management of human infections.

\section{REFERENCES}

Alfonso, C., Jesús Martínez, M., and Reyes, F. (1992). Purification and properties of two endochitosanases from Mucor rouxii implicated in its cell wall degradation. FEMS Microbiol. Lett. 95, 187-194. doi: 10.1111/j.1574-6968.1992.tb05364.x

\section{AUTHOR CONTRIBUTIONS}

$\mathrm{KL}$ and BS developed the ideas and drafted the manuscript. $\mathrm{MC}, \mathrm{JL}$, and PC collected the literatures and drew the figures. $\mathrm{KL}$ and BS professionally edited the manuscript.

\section{ACKNOWLEDGMENTS}

We thank Val Hopwood for careful editing of the manuscript.

Almeida, C. A., de Camos-Takaki, G. M., Portela, M. B., Travassos, L. R., Alviano, C. S., and Alviano, D. S. (2013). Sialoglycoproteins in morphological distinct stages of Mucor polymorphosphorus and their influence on phagocytosis by human blood phagocytes. Mycopathologia 176, 183-189. doi: 10.1007/ s11046-013-9692-6 
Angebault, C., Lanternier, F., Dalle, F., Schrimpf, C., Roupie, A. L., Dupuis, A., et al. (2016). Prospective evaluation of serum $\beta$-glucan testing in patients with probable or proven fungal diseases. Open Forum Infect. Dis. 3:ofw128. doi: 10.1093/ofid/ofw128

Araki, Y., and Ito, E. (1975). A pathway of chitosan formation in Mucor rouxii. Enzymatic deacetylation of chitin. Eur. J. Biochem. 55, 71-78. doi: 10.1111/ j.1432-1033.1975.tb02139.x

Bartnicki-Garcia, S., and Reyes, E. (1964). Chemistry of spore wall differentiation in Mucor rouxii. Arch. Biochem. Biophys. 108, 125-133. doi: 10.1016/0003-9861(64)90363-7

Bartnicki-Garcia, S., and Reyes, E. (1968). Polyuronides in the cell walls of Mucor rouxii. Biochim. Biophys. Acta 170, 54-62.

Bartnicki-Garcia, S., and Lindberg, B. (1971). Partial characterization of mucoran: the glucuronomannan component. Carbohydr. Res. 23, 75-85.

Battaglia, E., Benoit, I., van den Brink, J., Wiebenga, A., Coutinho, P. M., Henrissat, B., et al. (2011). Carbohydrate-active enzymes from the zygomycete fungus Rhizopus oryzae: a highly specialized approach to carbohydrate degradation depicted at genome level. BMC Genomics 12:38. doi: 10.1186/1471-2164-12-38

Bitar, D., Lortholary, O., Le Strat, Y., Nicolau, J., Coignard, B., Tattevin, P., et al. (2014). Population-based analysis of invasive fungal infections, France, 2001-2010. Emerg. Infect. Dis. 20, 1149-1155. doi: 10.3201/eid2007.140087

Bitar, D., Van Cauteren, D., Lanternier, F., Dannaoui, E., Che, D., Dromer, F., et al. (2009). Increasing incidence of zygomycosis (mucormycosis), France, 1997-2006. Emerg. Infect. Dis. 15, 1395-1401. doi: 10.3201/eid1509.090334

Bouchara, J. P., Oumeziane, N. A., Lissitzky, J. C., Larcher, G., Tronchin, G., and Chabasse, D. (1996). Attachment of spores of the human pathogenic fungus Rhizopus oryzae to extracellular matrix components. Eur. J. Cell Biol. 70, 76-83.

Camacho-Aguero, S., Balcazar-Orozco, R., and Flores-Carreón, A. (1990). Biosynthesis of polyuronides in Mucor rouxii: partial characterization of fucosyl transferase. Exp. Mycol. 14, 227-233. doi: 10.1016/0147-5975(90)90020-T

Campos-Takaki, G. M., Dietrich, S. M. C., and Beakes, G. W. (2014). "Cytochemistry, ultrastructure and $\mathrm{x}$-ray microanalysis methods applied to cell wall characterization of Mucoralean fungi strains" in Microscopy: Advances in Scientific Research and Education. ed. A. Mendez-Vilas (Formatex), 121-127.

Chamilos, G., Ganguly, D., Lande, R., Gregorio, J., Meller, S., Goldman, W. E., et al. (2010). Generation of IL-23 producing dendritic cells (DCs) by airborne fungi regulates fungal pathogenicity via the induction of $\mathrm{T}_{\mathrm{H}}-17$ responses. PLoS One 5:e12955. doi: 10.1371/journal.pone.0012955

Datema, R., van den Ende, H., and Wessels, J. G. (1977a). The hyphal wall of Mucor mucedo. 1. Polyanionic polymers. Eur. J. Biochem. 80, 611-619.

Datema, R., Wessels, J. G., and van den Ende, H. (1977b). The hyphal wall of Mucor mucedo. 2. Hexosamine-containing polymers. Eur. J. Biochem. 80, 621-626.

Davis, L. L., and Bartnicki-Garcia, S. (1984a). Chitosan synthesis by the tandem action of chitin synthetase and chitin deacetylase from Mucor rouxii. Biochemistry 23, 1065-1073.

Davis, L. L., and Bartnicki-Garcia, S. (1984b). The coordination of chitosan and chitin synthesis in Mucor rouxii. J. Gen. Microbiol. 130, 2095-2102.

de Ruiter, G. A., van der Lugt, A., Voragen, A., Rombouts, F., and Notermans, S. (1991). High-performance size-exclusion chromatography and ELISA detection of extracellular polysaccharides from Mucorales. Carbohydr. Res. 215, 47-57. doi: 10.1016/0008-6215(91)84006-Z

de Ruiter, G. A., Josso, S., Colquhoun, I., Voragen, A., and Rombouts, F. (1992). Isolation and characterization of $\beta(1-4)$-D-glucuronans from extracellular polysaccharides of moulds belonging to Mucorales. Carbohydr. Polym. 18, 1-7. doi: 10.1016/0144-8617(92)90181-O

de Ruiter, G. A., Van Bruggen-Van der Lugt, A. W., Mischnick, P., Smid, P., Van Boom, J. H., Notermans, S. H., et al. (1994). 2-O-methyl-D-mannose residues are immunodominant in extracellular polysaccharides of Mucor racemosus and related molds. J. Biol. Chem. 269, 4299-4306.

Dow, J. M., and Villa, V. D. (1980). Oligoglucuronide production in Mucor rouxii: evidence for a role for endohydrolases in hyphal extension. J. Bacteriol. 142, 939-944.

Dow, J. M., Darnall, D. W., and Villa, V. D. (1983a). Two distinct classes of polyuronide from the cell walls of a dimorphic fungus, Mucor rouxii. J. Bacteriol. 155, 1088-1093.

Dow, J. M., Olona, P. M., and Villa, V. D. (1983b). Glucuronosyl transferase from the dimorphic fungus Mucor rouxii. Exp. Mycol. 6, 329-334.
Flores-Carreón, A., Balcazar, R., and Rui'z-Herrera, J. (1985). Characterization of glucuronosyl transferase from Mucor rouxii: requirement for polyuronide acceptors. Exp. Mycol. 9, 294-301. doi: 10.1016/0147-5975(85)90002-7

Gebremariam, T., Liu, M., Luo, G., Bruno, V., Phan, Q. T., Waring, A. J., et al. (2014). CotH3 mediates fungal invasion of host cells during mucormycosis. J. Clin. Invest. 124, 237-250. doi: 10.1172/JCI71349

Gomes, M. Z. R., Lewis, R. E., and Kontoyiannis, D. P. (2011). Mucormycosis caused by unusual mucormycetes, non-Rhizopus, -Mucor, and -Lichtheimia species. Clin. Microbiol. Rev. 24, 411-445. doi: 10.1128/ CMR.00056-10

Gow, N. A. R., Latge, J. P., and Munro, C. A. (2017). The fungal cell wall: structure, biosynthesis, and function. Microbiol. Spectr. 5, 1-25. doi: 10.1128/ microbiolspec.FUNK-0035-2016

Ghuman, H., and Voelz, K. (2017). Innate and adaptive immunity to Mucorales. J. Fungi 3, 48. doi: 10.3390/jof3030048

Ibrahim, A. S., Bowman, J. C., Avanessian, V., Brown, K., Spellberg, B., Edwards, J. E. Jr., et al. (2005). Caspofungin inhibits Rhizopus oryzae 1,3-beta-D-glucan synthase, lowers burden in brain measured by quantitative PCR, and improves survival at low but not a high dose during murine disseminated zygomycosis. Antimicrob. Agents Chemother. 49, 721-727. doi: 10.1128/AAC.49.2.721-727.2005

Jones, D., Bacon, J. S. D., Farmer, V. C., and Webley, D. M. (1968). Lysis of cell walls of Mucor ramannianus Möller by a Streptomyces sp. Antonie Van Leeuwenhoek 34, 173-182. doi: 10.1007/BF02046428

Kafetzopoulos, D., Martinou, A., and Bouriotis, V. (1993). Bioconversion of chitin to chitosan: purification and characterization of chitin deacetylase from Mucor rouxii. Proc. Natl. Acad. Sci. USA 90, 2564-2568.

Latgé, J. P., and Calderone, R. (2002). Host-microbe interactions: fungi invasive human fungal opportunistic infections. Curr. Opin. Microbiol. 5, 355-358. doi: 10.1016/S1369-5274(02)00343-0

Latgé, J. P. (2010). Tasting the fungal cell wall. Cell. Microbiol. 7, 863-872. doi: $10.1111 / \mathrm{j} .1462-5822.2010 .01474 . \mathrm{x}$

Lending, C. R., Leal-Morales, C. A., Flores-Martinez, A., Bracker, C. E., and Bartnicki-Garcia, S. (1991). Purification and characterization of 16 S chitin synthetase particles from cell walls of Mucor rouxii. Exp. Mycol. 15, 11-25.

Lopez-Romero, E., Ruiz-Herrera, J., and Bartnicki-Garcia, S. (1978). Purification and properties of an inhibitory protein of chitin synthetase from Mucor rouxii. Biochim. Biophys. Acta 525, 338-345.

Lopez-Romero, E., Ruiz-Herrera, J., and Bartnicki-Garcia, S. (1982). The inhibitory protein of chitin synthetase from Mucor rouxii is a chitinase. Biochim. Biophys. Acta 702, 233-236.

Ma, L. J., Ibrahim, A. S., Skory, C., Grabherr, M. G., Burger, G., Butler, M., et al. (2009). Genomic analysis of the basal lineage fungus Rhizopus oryzae reveals a whole-genome duplication. PLoS Genet. 5:e1000549. doi: 10.1371/journal.pgen.1000549

Machida, S., and Saito, M. (1993). Purification and characterization of membranebound chitin synthase. J. Biol. Chem. 268, 1702-1707.

Mormeneo, S., Zazueta-Sandoval, R., and Flores-Carreón, A. (1995). Isolation and partial characterization of uronic acid-containing glycoproteins from Mucor rouxii. Curr. Microbiol. 30, 237-241. doi: 10.1007/BF00293639

Pedraza-Reyes, M., and Lopez-Romero, E. (1989). Purification and some properties of two forms of chitinase from mycelial cells of Mucor rouxii. J. Gen. Microbiol. 135, 211-218. doi: 10.1099/00221287-135-1-211

Petrikkos, G., Skiada, A., Lortholary, O., Roilides, E., Walsh, T. J., and Kontoyiannis, D. P. (2012). Epidemiology and clinical manifestations of mucormycosis. Clin. Infect. Dis. 54(Suppl. 1), S23-S34. doi: 10.1093/cid/cir866

Roden, M. M., Zaoutis, T. E., Buchanan, W. L., Knudsen, T. A., Sarkisova, T. A., Schaufele, R. L., et al. (2005). Epidemiology and outcome of zygomycosis: a review of 929 reported cases. Clin. Infect. Dis. 41, 634-653. doi: 10.1086/432579

Skiada, A., Lass-Floerl, C., Klimbo, N., Ibrahim, A., Roilides, E., and Petrikkos, G. (2018). Challenges in the diagnosis and treatment of mucormycosis. Med. Mycol. 56, S93-S101. doi: 10.1093/mmy/myx101

Skiada, A., Pagano, L., Groll, A., Zimmerli, S., Dupont, B., Lagrou, K., et al. (2011). Zygomycosis in Europe: analysis of 230 cases accrued by the registry of the European Confederation of Medical Mycology (ECMM) Working Group on Zygomycosis between 2005 and 2007. Clin. Microbiol. Infect. 17, 1859-1867. doi: 10.1111/j.1469-0691.2010.03456.x

Walsh, T. J., Groll, A., Hiemenz, J., Fleming, R., Roilides, E., and Anaissie, E. (2004). Infections due to emerging and uncommon medically important fungal pathogens. Clin. Microbiol. Infect. 10, 48-66. doi: 10.1111/j.1470-9465.2004.00839.x 
Yamazaki, H., Shiraishi, N., Takeuchi, K., Ohnishi, Y., and Horinouchi, S. (1998). Characterization of alg2 encoding a mannosyltransferase in the zygomycete fungus Rhizomucor pusillus. Gene 221, 179-184. doi: 10.1016/S0378-1119(98)00456-9

Conflict of Interest Statement: The authors declare that the research was conducted in the absence of any commercial or financial relationships that could be construed as a potential conflict of interest.
Copyright (c) 2019 Lecointe, Cornu, Leroy, Coulon and Sendid. This is an openaccess article distributed under the terms of the Creative Commons Attribution License (CC BY). The use, distribution or reproduction in other forums is permitted, provided the original author(s) and the copyright owner(s) are credited and that the original publication in this journal is cited, in accordance with accepted academic practice. No use, distribution or reproduction is permitted which does not comply with these terms. 